\title{
Colour and Organization Studies
}

\author{
Beyes, Timon
}

Document Version

Accepted author manuscript

Published in:

Organization Studies

DOI:

10.1177/0170840616663240

Publication date:

2017

License

Unspecified

Citation for published version (APA):

Beyes, T. (2017). Colour and Organization Studies. Organization Studies, 38(10), 1467-1482.

https://doi.org/10.1177/0170840616663240

Link to publication in CBS Research Portal

\section{General rights}

Copyright and moral rights for the publications made accessible in the public portal are retained by the authors and/or other copyright owners and it is a condition of accessing publications that users recognise and abide by the legal requirements associated with these rights.

Take down policy

If you believe that this document breaches copyright please contact us (research.lib@cbs.dk) providing details, and we will remove access to the work immediately and investigate your claim. 


\section{Colour and Organization Studies}

\section{Timon Beyes}

Journal article (Accepted version)

CITE: Colour and Organization Studies. / Beyes, Timon. In: Organization Studies. Article first published online: Oct ५, २०16.

Copyright [C [2016] (The Authors). Reprinted by permission of SAGE Publications.

DOl: https://doi.org/10.1177/0170840616663240

Uploaded to Research@CBS: August 2017 


\section{Colour and Organization Studies}

\section{Timon Beyes}

'Everything living tends to colour - to local, specific colour, to effect, to opacity pervading the minutest atoms. Everything in which life is extinct approximates to white (...), to the abstract, the general state, to clearness [Verklärung], to transparence' (Goethe, 1840: 234).

'Colour passes us by in the same way in which we do not notice our own breathing until it stops, by which time it's a little late' (Taussig, 2009: 243).

East-Berlin, 1957: Colour's deceit

A West German casino, a tale of the corrosive effects of money and gambling, of a lone, incorruptible journalist and his fight against the machinations and murderous intrigues of casino owner, drug dealer and editor-in-chief: Spielbank-Affäre (translated as Murder in the Casino) was planned to be the first colour movie produced and released by the state-run East-German film studios, Defa (Deutsche Film Aktiengesellschaft). An elaborate cinemascope production realized in cooperation with a Swedish production company, the film was meant to also target Western audiences. But to the committees of East Germany's Ministry of Culture through which Defa films first had to pass, the flashy production posed a problem: it was too colourful. To some officials, its flashiness was deemed to be too risky, potentially glamorizing Western conditions of life, notwithstanding the film's storyline. After a final preliminary screening in front of party and government representatives, a solution was found: Spielbank-Affäre would need to be shown in black-and-white. This way, the film's 'dangerous attractiveness' could be avoided, the Secretary of Culture was quoted as saying (N.N., 1957: 61; transl. T.B.). Against the will of movie director and 
Defa board, it had to be "decolourized" and translated into black-and-white. Which is a rather different process than shooting in black and white and nuanced tones of grey: The movie finally premiered in sluggish and dreary monochromes, a wholly different film than the one imagined by its creators.

Colour is dangerous. It 'deceives continuously', the Bauhaus artist and teacher Josef Albers writes in his classic book on Interaction of Colours (2013: 1). Whoever 'claims to see colours independent of their illusionary changes' is fooled (p. 23). The etymology of colour reveals such a deception, the Latin celare meaning to conceal or hide away. Its hues and tones, or so it seems, simultaneously reveal and conceal. The East German censors knew or felt that the film's chromatic seductiveness had the power to elude or contradict the lessons of its storyline.

The censors' perceptions, thoughts and actions indicate how colour shapes organization. In reorganizing experience, it acts as a 'medium of all changes' (Benjamin, 2011a: 211) that calls forth organizational action. To approach colour as a medium implies that it is a relational phenomenon. More precisely, it is relational in a double sense: Its effects are contingent upon the interactions of simultaneous contrast and complementarity between different hues, tints and tones; and it affects and connects subjects and objects, 'fills and forms the world', thereby co-constituting what is given to experience and 'making possible [...] sensing and being sensed, knowing and being known' (Cubitt, 2014: 2). The notion of 'medium of changes' moreover suggests that colour can be understood as a moving, processual force, as an ongoing 'play of expression and concealment' (Menke, 2013: 44). ${ }^{1}$ In the play of revealing and concealing, colour animates matter and is awash with affect; this way, it is 'capable of effecting events and transformations' (Eaton, 2013: 13). It is not, then, merely a secondary symptom of primary organizational structures or forms. It directly provokes, intervenes in and conditions organizational processes.

What might happen if the study of organization awakens to the ubiquity and efficacy of colour? Based on an appreciation of colour as medium of transformation, this essay seeks to open up the study of organization to the agency and dynamic, danger and potential of colour. Guided by a number of "colour scenes", the aim is to probe and develop the contours of a chromatics of 
organizing. The notion of chromatics here means theorizing colour's efficacy without enacting a clear-cut split between perceiver and perceived (Brusatin, 1991). A chromatics of organizing is thus dedicated to the questions of how colour affects organization, how organization affects colour, and what this means for the study of organization.

The emphasis on colour's relational and transformative mediality situates this endeavour in a tradition of thought and experiment dedicated to chromatic effects, to what colour does rather than what colour is. It acknowledges colour's 'uncanny ability to evade all attempts to codify it systematically', and its refusal 'to conform to schematic and verbal systems', even to 'conform to itself physically' (Riley, 1995: 1, 12). Colour's contingent, formless form and aesthetic force are in this sense irreducible to explanatory frameworks based on physical matter (Cohen \& Matthen, 2010), the experiencing subject (Palmer, 1999) or linguistic codes (Biggam, 2015). As if behaving on its own terms, colour has proved to be supremely indifferent to the scholarly categories, definitions and ordering systems designed to capture it. In Wittgenstein's memorable words, '[w]e stand there like the ox in front of the newly-painted stall door' (1978: 16e).

So far, the study of organization has neglected or taken for granted colour as organizational phenomenon and force in its own right (for an exception, see Connellan, 2013). In redressing this peculiar colour-blindness, a chromatics of organizing enters into a dialogue with a number of developments in organizational theorizing that are woven into the course of this essay. For one, it is connected to a processual approach that sees organization as extracted from a relational, continuously connecting and disconnecting interplay of dynamics (Cooper, 2005; Helin et al., 2014). Then, as part of a more general turn (back) towards the aesthetic in contemporary thought (Jameson, 2013; Rancière, 2013; Reckwitz, 2012) it offers a distinct contribution to the field of organizational aesthetics (Gagliardi, 2006; Strati, 2010; Taylor and Hansen, 2005) and the recent engagement with the visual in organization studies (Bell et al., 2014). As the introductory scene shows, the aesthetic here is not conceived as a property of objects or experiencing subjects but as force that underpins and transforms social relations (Menke, 2013). Attending to colour therefore calls for a processual aesthetics of the ordering and disordering of what can be sensed (Beyes, 2016), 
expanding organization studies' 'ocularcentrism' (Kavanagh, 2004) towards other sensory modalities and their material and embodied conditions (Küpers, 2014). While this essay draws upon a different trajectory of thought, its approach and implications moreover can be connected to - and add to - recent work on organization as a relational and spatial configuration of affects or atmospheres (Beyes \& Steyaert, 2012; Borch 2010; Knox et al., 2015) as well as their multiple entanglements of bodies, media and matter (Beyes \& Steyaert, 2013; Dale \& Latham, 2015; O'Doherty, 2008). These configurations carry their own politics of aesthetics (Rancière, 2004). As an organizational force, colour becomes an instrument of control and repression (Connellan, 2013), or 'colour management' (Blaszczyk, 2012). At the same time, however, colour is dangerous; it betrays, undermines and subverts such logics. Consider the East German bureaucrats, grappling with the chromatic power to simultaneously reveal and deceive.

The form of the essay - anti-systematic, explorative, eschewing the fantasy of complete understanding and rigid conceptual frameworks (Adorno, 1984) - lends itself well to the movements of colour. It permits the presence of doubt and encourages 'a childlike freedom that catches fire, without scruple, on what others have already done' (p. 152). In this sense, the ensuing scenes present singular occurrences, set in different times and places, around which a network of perceptions, ideas, speculations and connections can be woven (Rancière, 2013: xi). They assemble a heterogeneous cast of artists and thinkers who share a keen sensibility for what colour does. The scenes are representative only in the sense that they offer particular snapshots of the relational medium of colour and how it might affect the study of organization.

The next scene takes place in Weimar, where at the end of the $18^{\text {th }}$ century Goethe grapples with what, in retrospect, is regarded a foundational act of thinking chromatics in terms of its effects, its 'mattering' (Cubitt, 2014: 143). From the poet's experiments with colour's relational, processual and generative force the essay then cuts to Thomas Pynchon's 'fictitious' space: The Zone in the novel Gravity's Rainbow, which enacts an uncanny organizational history of synthetic dyes and hues. From there it seems but a step to pre-war Berlin and Benjamin's chromatic experiences of the mattering of colours that are attached to commodities and advertisements. The wonder and danger 
of colour, its magic and poison, are reframed as a constitutive and productive ambiguity. Finally, there is an encounter with the painter Gerhard Richter's aleatory composition of digital colours in present-day Cologne, restaging the question of what colour can do in the age of digital reproduction and modulation. The conclusion is given over to the contours and the potential of a chromatics of organizing that is able to appreciate how colour affects organization, and how it is reorganized in return.

Weimar, 1790-1810: Cooking chocolate

The poet is boiling chocolate. For him, it is a scientific experiment, one of many in an ingenious series of attempts to open up colour, to demonstrate its complexity and wonder and to restore it to 'the general dynamic flow of life and action' (Goethe, 1840: 298). Documented in his Theory of Colours, published in 1810 and 'still the most comprehensive study of colour' (Gage, 1999: 169), the plethora of everyday experiments was driven by the eccentric quest to map an understanding of colour that includes the human observer. This understanding thus needs to accommodate both natural processes that transcend the merely human and the generative agency of human sensation and subjectivity. The Theory entailed pioneering forays into what would later become the physiology and the psychology of colour perception as well as a veritable history of knowledge about chromatics. ${ }^{2}$ It is his most important work, Goethe would later say. His obsession with colour is fuelled by a passionate quest to counter and contradict what he perceived to be the poverty of Newton's theory of light and the colour spectrum, and the straightjacket of its totalizing truth claims (Sepper, 1988).

So how is "life" put back into colour? Closely observing the emerging bubbles when boiling chocolate, Goethe describes how 'coloured lines chase each other over the surface' while 'all the colours of the scale are seen to pass through each other' (1840: 193). On the highest point of a larger bubble,

'we see a small circle appear, which is yellow in the centre; the other remaining coloured lines move constantly round this with a vernicular ["wormlike"] action. In a short time, the circle 
enlarges and sinks downwards on all sides; in the centre the yellow remains; below and on the outside it becomes red, and soon blue; below this again appears a new circle of the same series of colours: if they approximate sufficiently, a green is produced by the union of the border colours' ( $p$. 194).

Colour does not stand still. It is 'ever in movement', more power than object (p. 300). It seems formless or beyond or before form, hovering on the edge of human perception. Goethe, writes Deleuze (2005: 97), is the first to explore and think 'colour-space', which is available for an infinite number of transformations. As Benjamin emphasized in his early fragments Dialogue on the Rainbow and A Child's View of Colour, colour is the 'medium of all changes, and not a symptom'; 'wherever it is not confined to illustrating objects', it is 'full of movement' and 'arbitrary' (Benjamin, 2011a: 211-212; 2011b). As medium of transformation, it is relational: It affects objects and subjects, and a colour takes on meaning and intensity in association with, or contrast to, other colours, 'which because they are indefinitely nuanced, make the value of a given colour infinitely variable' (Caygill, 1998: 13).

Colour here becomes a medium of, and colour-space a site of, transformation through momentarily disconnecting how we routinely make sense from the sensations our bodies encounter. The 'unmanageable thing' (Taussig, 2009: 17), then, 'not to be arrested' (Goethe, 1840: 300), is a strange in-between phenomenon, an atmospheric agent that eludes or dissolves the fixed categories of subject and object: not inherent in things, it does not fully belong to the experiencing subject, either. That colour messes up the doubling of reality into subjects and objects, 'fall[ing] through the cracks of Western self-making and the everyday sense as to the makeup of the world', led to Goethe's irritation and wonder, writes Taussig (2009: 174). But then, the colours are 'mattering' (Cubitt, 2014: 143): one seems unable to identify them as separate entities without the substances or forms they emanate from; their manifestations are entwined with that from which they are supposedly separate. As Benjamin memorably put it, colour seems like 'something winged that flits from one form to the next' (2011a: 211). Yet '[i]t often flies contrary to our wish', the poet already remarked (Goethe, 1840: 237). 
With regard to the contours of a chromatics of organizing, at least three things follow. They concern the conceptual history that informs the notion of colour as organizational force, the way this history is translated into attempts to come to terms with colour and the ensuing epistemological and methodological implications. First, the Theory of Colours has been called perhaps the first critique of enlightened scientific optimism that does not resort to a romantic irrationalism (Brusatin, 1991). Alas, Goethe's hope for what today would be considered a transdisciplinary science of chromatics in its own right would be unmet; '[t]he world had learned to see with Newton, to see colour from the perspective that his optics had established' (Sepper, 1988: 99). Broadly put, ever since the advent of Newtonian physics there has been a split between the science and the art of colour, a disconnection that the Theory of Colours failed to redress (Gage, 1999). Perhaps, with Goethe's critique in 'failing' it was the ubiquitous world of colour that, by and large, slipped off the radar in dominant patterns of political, economic, social and cultural inquiry (Batchelor, 2008). It seems that the expressiveness, fluidity and changeability of colour is dangerous for the organization of organizational theorizing, too, its orderliness and cleanliness, where '[t]ruth (...) comes in black and white', fenced in 'with lines and marks, the boundary-riders of thought' (Taussig, 2009: 17). No wonder, indeed, that colour ever so rarely shows up in the academic production of knowledge (including this paper, printed as black inscribed upon white).

And yet, Goethe has become the founder of an alternative discourse of chromatics attuned to the world-making and protean force of colour. While the genealogy of this discourse remains to be written, due to a recent flurry of engagements with chromaticity as constitutive force in the Goethean sense, it seems very much alive. Apart from the rekindled engagement with colour in art theory and art history (Batchelor, 2008; Gage, 1995; Riley, 1995), there is a turn to chromatics in fields such as anthropology - with Taussig's What Colour is the Sacred? (2009) as influential text media theory (Cubitt, 2014; Kane, 2014), architectural theory (Lavin, 2004), cultural history (Pastoureau, 2001, 2009), postcolonial studies (Eaton, 2013) and affect theory (Manning 2008; Massumi, 2002). Thus there is a rich history and present of experiments, thoughts and descriptions that a chromatics of organizing can draw upon and pull into the study of organization. 
Second, the reception of Goethe's Theory of Colours offers a number of working assumptions on how to make sense of colour that provide a point of departure for a chromatics of organizing. To start, engaging with the organizational efficacy of colour means being attuned to its agency, to what colour does, rather than dwelling on the perennially contested problem of trying to define what it is. For instance, inquiring into the wave-length properties of light and how they determine hue, saturation and brightness yields no insights into how, invariably in relation or distinction to other hues, colour affects 'the sensible fabric of experience' (Rancière, 2013: x). With Goethe and Benjamin, colour can be grasped as a medium of transformation and thus as a processual, relational and productive force. According to Albers (2013), studying chromatics requires an acknowledgment of process and flux, of 'what went on, what moved, what developed' (p. 72), because 'what counts is not the what but the how' (p. 5). Pulling the expressivity, fluidity and changeability of colour into the study of organization thus leads to a chromatics of organizing: to a processual approach that sees organization as continuously extracted and performed from a relational field of aesthetic forces, where entities 'take second place to the continuous transmission of movement' (Cooper, 2005: 1689). Taussig calls it a 'polymorphous magical substance' (p. 40). It would affect not just sight, but all the senses (colour's affective capacity); it would materialize in countless changing forms (colour as material force); thus it would require a shift from thinking substance to apprehending movement (colour as medium of transformation). A chromatics of organizing is therefore attuned to the mediality, materiality, and affectivity of colour.

Third, Goethe did not just ponder the limits of language to present chromatic movement, coupled with a belief in the necessity to attempt thick descriptions of it. According to Taussig (2008: 6-7), the poet moreover performed 'the ur-scene of nomadic science' and thus enacted what, in unpoetic terms, constitutes a methodological innovation. Goethe entered into chromatic atmospheres and marvelled at colour's countless relational transformations into different tints, shades and tones. He thus disbanded the epistemological principle and representational model of the camera (obscura) eye as principle of truthful empiricist inquiry (Crary, 1988). ${ }^{3}$ Instead, he inserted himself into the movement of colour that affects the human body, pulling the perceiver into 
the perceived. This way, a chromatic way of sensing, and then making sense of, organized settings is opened up. Here, 'matter-force rather than matter-form seems to provide a more honest way of describing what is happening' (Taussig, 2008: 7). The history of attending to chromatic matter-force thus not only prefigures an aesthetic approach to (the study of) organization but also pushes further or perhaps radicalizes a turn towards aesthetic dimensions of organizing that are often simply taken for granted and that reside on the 'boundary of the knowable' (O'Doherty et al., 2013: 1435). A chromatics of organizing should thus bring further momentum to more recent explorations of a 'sensual methodology' (Warren, 2008) and apprehensions of the everyday production of organizational space and affect (Beyes and Steyaert, 2012). Moreover, it calls for a new poetics of organization (Linstead, 2000): modes of expression that attend to chromatic transformation and register the ensuing interruptions and shifts in organizational processes (Beyes \& Steyaert, 2013; Holt and Cornelissen, 2014; Knox et al, 2015).

The Zone, 1945: Colour Management

'Yes, Private, the colours change, and how! The question is, are they changing according to something? Is the sun's everyday spectrum being modulated? Not at random, but systematically, by this unknown debris in the prevailing winds? Is there information for us? Deep questions, and disturbing ones.' (Pynchon, 2000: 642)

One may prefer to keep a polymorphous magical substance safe in the world of art and poetry. But then, consider the emergence of colonial trade and mercantile capitalism, when the organization of production and exchange was partly predicated on colour, 'the coke of empire' (Eaton, 2013: 9; Taussig, 2009): cochineal from Mexico, red dye from Brazil, indigo from India, Persia and the Caribbean, and so on (Finlay, 2007). Towards the end of the $19^{\text {th }}$ century, the second industrial revolution, tied to the artificial generation of dyes, ushered in the downfall of the colonial trade in 
dyes and pigments (Pickering, 2005). In 1856, the first aniline dye, mauve or 'Tyrian purple', was accidentally discovered in London. It was the subsequent quest for locally produced, standardized colours that spawned the science of organic chemistry, which 'was born into the rainbow-hued world of the dye industry' (Delamare \& Guineau, 2000: 100). Not only were Westerners released from their 'chromatic inhibitions' and ready to 'outdo the barbarians', as the editors of Fortune declared in 1930 (quoted in Blaszczyk, 2012: 1). The magic of artificial colours also transformed the social relations of production and led to the dazzling realm of commodities as we know it. As Pickering (2005) showed, this industrial revolution reconfigured the relations between forms of production, law and a practice of science that was progressively geared towards industrial concerns. Yet this, too, is a story of colour and its material-affective force, flitting from one form to the next. 'In transforming valueless matter (waste from animals and machines) into a shiny new colour, dead matter was magically gifted with a second life. Colour's mysterious alchemy and unpredictable behaviour prevailed, even at the height of the industrial age' (Kane, 2014: 46). ${ }^{4}$

Perhaps no other text is as attuned to this mysterious alchemy and the organizational effects of the polymorphously perverse substance of synthetic colour like Thomas Pynchon's novel Gravity's Rainbow. Indeed, Gravity's Rainbow can be read as a radical example of a poetics of organization that reflects and performs a chromatics of organizing. For one, colours and their combinations appear as an organizing principle of a seemingly disjointed piece of fiction, reflecting the ambiguity of colour as medium for both enabling as well as routinizing and manipulating sensory experience (Hayles \& Eiser, 1985). Then, the novel, loosely set in Europe at the end of World War II and woven around the development of $\mathrm{V}-2$ rockets by the German military, makes ample use of the history of IG Farben, a consortium of German dye-making corporations ("Farben" means "colours"). In Pynchon's historically astute rendering, this vast corporate empire epitomizes the industrial world's propensity to translate the magic of generating shining colour from valueless matter into its abyssal flipside. ${ }^{5}$ The launch, flight and destructive impact of the rocket, its parabolic, 'rainbowshaped' trajectory once its engine is deactivated, is both predicated on and unleashes the magic of colour and its imaginative force. Hounded across 'The Zone', as Pynchon calls the war-ravaged and 
chaotic remnants of the Third Reich after VE day, a character called Thanatz - after Thanatos, i.e. death - remembers the last firing of a rocket close to the city of Lüneburg. Here is Thanatz recalling the chromatic wonders of the chemical-industrial age:

'An image keeps recurring - a muddy brown almost black eyeball reflecting a windmill and a jagged reticule of tree-branches in silhovette (...) in the iris sky one cloud, the shape of a clamshell, rises very purple around the edges, the puff from an explosion, something light ochre at the horizon ... closer in it seems snarling purple around a yellow that's brightening, intestines of yellow shadowed in violet spilling outward, outward in a bellying curve toward us' (Pynchon, 2000: 670).

Formed as a syndicate between Bayer, BASF and Agfa in 1904 and fully founded as a merger in 1925, IG Farben became the largest chemical corporation in the world. Its 'coal-tar Kabbalists' (Pynchon, 2000: 590) went from mainly manufacturing dyes, films and synthetic colour products to the production of synthetic nitrates, rubber and plastics, fuel oil and explosives - in other words, base materials for the next war (Hayes, 2001). Dangerous colour: Agfa, for one, moved from dyemaking via poison gases for World War I to mainly producing Technicolour film (its Agfacolour technology would later be used for the shooting of the film Spielbank-Affäre). IG Farben, meanwhile, profitably prospered in the Third Reich, among other things operating the Buna Werke factory in Auschwitz, run on forced labour by foreign workers and concentration camp inmates, producing synthetic oil and rubber. Zyklon B, the gas used in the camp, came from an IG Farben subsidiary. At the 'IG Farben Trial', held by the U.S. government after World War II, one former company director testified (quoted in Taussig, 2009: 218): 'I wanted to see my child, or some fish or game I had caught, in colour - to see it in all its beauty. And we succeeded'.

And they succeeded. 'Reliable colours are now so common that we never think about their significance', Regina Lee Blaszczyk (2012: 298) writes in her sumptuously illustrated study of The Colour Revolution from the 1890 s to the 1960 , accounting for how 'colour management' changed the world of business through design, fashion and consumption. But if colour deceives continuously, if it is both magic and poison, then it also unsettles charming stories of the chemical transformation of waste and dead matter into beautiful and benign forms of organizing life. ${ }^{6}$ Considering IG 
Farben's particularly frightening practices of colour management, the chromatic radicalism of Gravity's Rainbow lies not, or not primarily, in the depiction of IG Farben as a symbolic villain for the willing cooperation of industry with a fascist and murderous regime. ${ }^{7}$ Rather, colour organizes us away from ourselves. The novel insinuates that technological-industrial progress driven by the quest for dazzling colours is implicit with, or even drives, a dehumanizing and destructive development: 'the triumph of the rainbow at home' (Finlay, 2007: 429) simultaneously is a tragedy.

Pynchon's literary chromatics can thus be read as a sprawling, uncanny meditation on colour as relational medium of transformation: a history of synthetic dyes and hues as organizational force. They condition organizational conduct by driving industrial-scientific inventiveness, by affectively modulating what its actors sense, how they make sense and thus how they act, and by materializing in manifold forms and constellations. Yet this force is uncanny in the precise sense of the term (Beyes and Steyaert, 2013): it makes the familiar, homely world of reliable colours strange and unhomely, laying bare its implication in the business of destruction and exploitation. This way, the novel enacts and enables reflections on the politics of colour and of colour management. Not unlike the "natural" generation of exotic colours in colonial times, the synthetic production of hues and tones is connected to a ghastly mode of organization. The generation of bright and shining colours, of life from dead matter, is entwined with practices of exploitation and the fabrication of death. Exploring the organizational effects of the quest for dyes, hues and tones, it needs to be inferred, a chromatics of organizing requires a sensibility for colour's danger, its agency as polymorphous magical poison:

'Oh, a state begins to take form in the stateless German night, a State that spans oceans and surface politics, sovereign as the International or the Church of Rome, and the Rocket its soul. I.G. Raketen, Circus-bright, poster-reds and yellows, rings beyond counting, all going at once' (Pynchon, 2000: 566). 
Gravity's Rainbow lays out a terrifying scenery of colour's dual and intertwined capacity to enchant and to corrupt, and of the perpetual struggle of taming and profitably (as well as destructively) controlling its uncontrollable force. If anything, the contemporary 'chromo-utopia' (Blaszczyk, 2012: 298) enabled by Pynchon's 'coal-tar Kabbalists' makes it all the more puzzling that colour so rarely shows up in the study of organization. Perhaps we still do not 'understand just how colourful our current civilization is', writes Thrift (2008: 16). Pondering the rise of gaudy advertisement posters and the new world of products for sale in the $19^{\text {th }}$ century Paris Arcades, Walter Benjamin (2002: 173) is reminded of fairy tales:

'Falser colours are possible in the arcades; that combs are red and green surprises no one. Snow White's stepmother had such things, and when the comb did not do its work, the beautiful apple was there to help out - half red, half poison-green, like cheap combs. Everywhere gloves play a starring role, coloured ones but above all the long black variety on which so many (...) have placed their hopes for happiness.'

Such is consumerism's magical power. One might lament that the overabundance of 'falser colours' dilutes the quality of sensory experience; that '[w]e are losing our intimate connection with the materiality of colour, the attributes of colour that excite all the senses, not just sight' (Delamare \& Guineau, 2000: 125). Yet the synthetic colour of the beautiful apple, half red, half poison-green, attaches itself to commoditized objects and lends them a seductive veneer. Writing in 1968, Baudrillard (2005: 31-32) likens the advent of multiple bright hues and tones in homes and workspaces to 'a liberation stemming from the overthrow of a global order'. And above all it is 'the spheres of advertising and commerce, where colour's power to corrupt enjoys full rein' (ibid.: 34). Colour is the gift that lends aura to commodities. A liberating and corruptive force, both authentic and deceitful, magical and poisonous: such is its ambiguity.

Echoing the well-known argument about the magical property of the commodity, Taussig argues that the standardized mass production of aniline dyes and artificial hue turned colour into the 'commodity's commodity' (2009: 234), like labour providing the commodity with a surplus value that is bigger than what is needed for its mere reproduction and becoming a commodity in its own 
right. Again, the doubling of commodification plays out both affectively and materially. The mattering of colour, attaching itself to forms and objects, reorganizes the way everyday environments are experienced. Yet in the early $20^{\text {th }}$ century, colour as matter is itself ordered, measured, standardized and commoditized. Submitted to statistically generated norms and mapped unto colour tables and cards, colours are freed from their associations with objects; reliably identifiable, easily matchable and combinable, they become both autonomous exchange values and managerial tools (Cubitt, 2014). In this sense unperturbed by colour's capacity to deceive and corrupt, in her history of the managerial organization of colour Blaszczyk (2012) celebrates an impressive cast of latter-day colourists. These 'practical men' (p. 23) - 'colour stylists, colour forecasters, and colour engineers' (p. 290) as well as 'colour consultants' - ushered in the 'age of colour' and 'colour management' as social technology. Colour, 'something winged' and medium of transformation (Benjamin, 2011a: 211), here flings from the vagaries of fashion to interior design and the atmospheric conditioning of workers' and home dwellers' moods; it lends advertisements its intoxicating force and helps selling cars and numerous other consumer products; it performs the chromatic wonders of 'rainbow cities' (Blaszczyk, 2012: 191); it even becomes 'the ultimate tool of scientific management' (p. 229).

A chromatics of organizing is thus attuned to how the mattering of colour turns it into both commodity and managerial tool: into the commodity's commodity. It therefore should be of utmost interest to a critique of organizational aesthetics (Carr and Hancock, 2003) that seeks to understand how the social and human bodies are organized through processes of aestheticization (Reckwitz, 2012; Taussig, 2012). Such aestheticization relies on what Thrift calls 'a new art of illumination', denoting the prominence of luminosity and hue, of bold and bright colours that construct 'convincing images' and cultivate a new 'proto-environment' (Thrift, 2012: 154); colour is prominently involved in what Cubitt calls the 'biopolitical management of commercial novelty and governed predictability' (Cubitt, 2014: 151). ${ }^{8}$ Given its capacity to animate matter, then, it needs to be problematized how the modulation and engineering of affect through colour works on consumerist monads and docile employees who are held 'interidiotically stable' (Thrift, 2008: 12). 
And yet, the medium of changes seems too ephemeral and unmanageable to be merely distilled into distinct and instrumentally combinable elements. Benjamin, so attuned to chromatic experience, sensed this. Here is a short, mesmerizing scene, taken from the collection of short aphoristic paragraphs called One-Way-Street, written in 1925/26:

'What, in the end, makes advertisements so superior to criticism? Not what the moving neon red sign says - but the fiery pool reflecting it in the asphalt' (Benjamin, 1979: 89-90).

Benjamin's street scene can be read as resigned and melancholic, condensing into a few words the inferiority of conventional criticism, black marks on white paper, vis-à-vis the cacophony and the movements of synthetic, luminous colours. Yet, at the same time it insists on colour's fundamental ephemerality, on its ever-shifting, formless form, its potential 'to perform its magic acts of appearing and disappearing and reappearing' (Batchelor, 2014: 59). Its continuous transformation even on the asphalt beneath our feet indicates a 'speculative excess of colour over the forms of experience in which it finds itself' (Caygill, 1998: 150). Colour again escapes, this time the form of a neon red sign, becoming a reflection in a pool of water, as ever reflecting 'the possibility (...) of a reorganisation of experience through colour' (Caygill, 1998: 152). In her exploration of white as organizational colour, Connellan (2013) has similarly pointed towards the simultaneously 'both uplifting and suppressing' (p. 1546) character of white surfaces and spaces, which assert control just as they invite subversion. An organizational chromatics therefore needs to acknowledge colour as medium of transformation and to assume its doubling capacity as ambiguous organizational force: as a means of unlocking opportunities for the purpose of power and profit, and as an opening of new possibilities of what can be sensed.

\section{Cologne, 2007: Monotonous polychromy}

Colour's constitutive ambiguity, its 'dialectics of control and randomness' (Cubitt, 2014: 111), has been explored most attentively on the terrain of visual art. ${ }^{9}$ As Marcel Duchamp ironically said in 1961, in an age where colour pigments are standardized and mass-produced by industrial machines and thus ready-mades, 'all the paintings in the world are "readymades aided"' (Duchamp, 1966: 47). 
Colour in its industrial state, or so it seems, is unable to live up to ideas of 'chromatic consolation', since even painting is incapable of countering the co-optation of colour as social technology in the hands of advertisement and product design (Buchloh, 2012: 170).

As if enacting a painterly reflection of this conundrum, the artist Gerhard Richter, among many other things in his oeuvre, has repeatedly engaged with the potential of chromaticity in the age of mechanical, then digital, reproduction. In 1966, Zehn Farben (Ten Colours) simply presented a table of colours, akin to those used as industrial standards in and for commercial settings, allowing for the commodification of colour itself. As a reproduction of a principle of order enacted by the commercial codification of hues and its easy, practical use, Ten Colours perhaps pointed to the inability of transcending colour's status as 'just another industrial readymade' (Buchloh, 2012: 170). In 2007, his Cologne Cathedral Window was unveiled. Responding to the prestigious task of painting the Cathedral's south transept, Richter went back to his 1974 colour scale 4096 Farben ( 4096 Colours), in which a spectrum of 1024 hues and tones appears four times in a composition dictated by a mathematical formula of chance. The Cathedral Window, which consists of approximately 11,500 glass squares, radicalizes this 'aleatory dissemination and permutational multiplication of colour in noncompositional arrangements' (Buchloh, 2012: 170) through a chance distribution of 72 colours enacted by an aleatoric computer program. Instead of depicting theological scenes or figures in divine colours, there is an abstract kaleidoscope in the form of a randomly generated (dis)order of square elements, which 'cannot help but allude to the flat and low-resolution coloured graphics of the web' (Kane, 2014: 290).

In this sense, the Cathedral Window and its 'monotonous polychromy' (Buchloh, 2008: 70) has been interpreted as a response to the world of millions of digitally programmed colours. As a technoid abstraction, it reflects the mathematization of colour and that today, it is algorithms that condition what it can do. Digital technologies have ushered in the next stage in the process of standardizing, quantifying and controlling colour schemes untied from the perishable and instable base of natural materials (Crary, 2006). And colour in its electronically mediated form again is at the forefront of the struggle for consumer perception. The millions of tints, shades and tones promised 
by the new synthetic lifeworld, which far surpass a human being's capacity to distinguish between them, indicate the next stage of colour management at work on mass consumerism as well as internet commerce and its captivating surfaces. They produce 'a spirited sense of colour, which goes beyond colour as such in that it incorporates tactile movement - wheelings and pivotings and splicings - into its effect' (Thrift, 2012: 154).

Today's digital colourists, then, do not touch colour; they program it. The question of the mattering of colour, of which objects and forms it attaches itself to, switches to an informationtheoretical materialism. As the media theorist Friedrich Kittler wrote in a text called Thinking Colours and/or Machines (2006: 49), it is now 'media technologies constructed on the basis of formal languages' that 'move the boundary between the possible and the impossible, the thinkable and the unthinkable'. In this sense, Richter's digitally programmed distribution of hues and tones as a structural organization of painting seems to indeed demonstrate that, as Kittler famously claimed (1999: 2), '[w]ith numbers, anything goes'. And the vibrant, highly saturated yet cold hues of democratized colour that we tinker with on social media platforms, with Photoshop or PowerPoint, hinge on and are shaped and controlled by the inscrutable calculations of data sets.

And yet, upon entering the Cologne Cathedral, it seems like the indeterminacy of colour relations is digitally multiplied, made more unpredictable and erratic, elevating the coincidences of colour as relational composition (Pelzer, 2008). Far from perceptions of a cool and calculated assemblage of hues, the colours emanating from the stained glass seem to uncontrollably shimmer, flicker, glow and glisten inside the gloomy grandeur of the church. As transparent and 'cool' as each square element is, it shifts in conjunction with the randomly arranged mass of other squares. When the light of day outside of the Cathedral changes, the hues and their tints, shades and tones change, too: awash in glowing multi-coloured light when caught by direct sunlight, decreasing and increasing in intensity with the movements of the clouds. All colour, it seems, is continuously changing, is movement, winged creature flicking from one state to the next.

Echoing media theorist Mark Hansen's discussion of an immersive colour installation by the Danish artist Olafur Eliasson, Richter's Cathedral Window seems to occupy the space between the 
digital modulation of colour and its qualitative perception. It produces a colour-space that attests to the potential of an inchoate sensory life where the transition from engineered affect to sense perception, and what can be made of it, is kept open (Hansen, 2013). Here, the process of random algorithmic composition enacts its own polymorphous magic; colour, still and as always, is both form(alized) and formless. Yes, Richter's chromatic play seems to signal after it has struck the awed perceiver and thinking kicks in, colour has been subjected to mechanization and limitless technological modulation. But at the same time it manifestly attaches itself 'to new forms of resistance to and subversion of the forms of power inherent in accident and aleatory organization' (Buchloh, 2012: 171-173). The potential of chromaticity is not exhausted in technologies of mechanical or digital engineering; they, too, enable the sheer presence, intensity and openness of colour relations.

\section{Broken tones: Colour and Organization Studies}

This essay pursued the question of what would happen if the study of organization would awaken to the ubiquity and efficacy of colour. The little montage of colour scenes assembled in the previous pages - and the concepts, observations and speculations attached to them - sought to probe how the uncharted territory of colour and organization can be imagined and explored.

Moving towards a conclusion, and first and foremost, colour matters. It ought to become a phenomenon of profound concern to organization scholars. 'Look! Look at colour! Become aware!', Taussig demands (2009: 243; orig. emphasis). To instigate such becoming-aware, this text has been based on a (counter-)history of chromatics from Goethe onwards, which acknowledges colour's unruliness and grapples with what it does or can do. The scenes assembled in this essay have therefore been connected to Benjamin's notion of 'medium of changes' and Taussig's more delirious term of 'polymorphous magical substance'. Both convey a sense of colour's force, its relational power to animate matter and affect bodies, as well as its ambiguity in oscillating between managerial tool and enabler of alternative experiences and perceptions. 
As a primary organizational force, then, colour provokes yet is irreducible to the world of signs and of metaphors for desired or undesired states and emotions (Massumi, 2002) or to accounts of how specific hues psychologically determine behaviour, which perhaps represent the study of chromatics '[a]t the most impoverished level' (Baudrillard, 2005: 31). Colour shapes yet cannot be limited to the sphere of ornament and decoration, the paint on our walls, the hue of our shirt, the dye of our pair of jeans (Taussig, 2009). It expresses yet cannot be reduced to mere personal taste, to an appendage of traditions, rituals or layers of social stratification (Baudrillard, 2005). Of course, different narratives of colour contribute to understandings and enactments of what colour can(not) do (Brusatin, 1991). In this sense, the present essay only offers a map of beginnings of, or prolegomena for, a more sustained engagement with colour and organization (studies).

What, then, are the contours of a chromatics of organizing? Borrowing Martin's (2003) reflections on architecture and 'the organizational complex', one can tentatively approach colour and organization 'as partial and uneven functions of one another' (p. 8). While organization is of course not just an offshoot of unleashing colour unto the world, colour affects organization and is affected by organization. As polymorphous magical substance and medium of transformation, colour provokes, conditions, disrupts and alters how organization takes place and unfolds. Based on the preceding scenes, a chromatics of organizing affords interrogations of how the quest for colours establishes organizational practices and forms; how colours become a tool or technology of organizing; how colours intervene in and change organizational conduct; and how colours transform the embodied perceptions of and in organized settings. Along these preliminary lines, the project of a chromatics of organizing can be further developed and take shape. Moreover, that the amount of potential empirical sites for such analyses seems limitless testifies to colour's ubiquity and efficacy as organizational force.

As indicated, a chromatics of organizing enters into a productive dialogue with a number of developments in the study of organization. First and perhaps foremost, it can give a push to research on the aesthetics of organization by "colouring" its awareness of the corporeality of sensible knowledge and its focus on the modulation and engineering of symbols and artefacts. 
Colour is now recognized as a prime agent of contemporary and historical processes of aestheticization and their social, economic and political implications. Without colour, commodity culture and contemporary capitalism seem unthinkable, which makes inquiring into the chromatic conditioning of organization indispensable. However, chromatic mediality calls for an aesthetics of force, of process, where the interplay of colours enables and shapes, confounds and reorders the relations of objects and sense experience. With regard to colour, then, interpreting the aesthetic either instrumentally or critically and singling out either organizational artefacts or the experiencing subject does not suffice. Colour thus opens up the enticing possibility of an aesthetics of organization that attends to the movements of organizing through the moving, formless yet relational form of colour and the ordering and disordering of situational knots of what can be sensed, thought and expressed. Investigating the mattering of colour thus also contributes to recent engagements with affect theory and the affective constitution of organization as well as reconsiderations of the notion of sense-making in organized settings, in which a turn to chromatics would help to 'think-feel' how '[c]olour is thinking's affective accompaniment' (Massumi and Manning, 2014: 80; emphasis removed). Moreover, the recognition of colour's uniqueness and its sheer ubiquity requires that organizational scholars reimagine the way they see (or rather 'feel-see', to paraphrase Massumi and Manning). To be struck by colour according to Albers (2013) requires a 'sensitive eye' (p. 65), a 'thinking in situations' (p. 9) - or scenes - and an imaginative sensibility for the potential of colour. A sensitive eye, a thinking in situations, an imaginative sensibility: it seems we are back with Goethe, opening up to, attentively following and trying to put into words the shifting formations of hues and tones, their capacity to affect and their ever-changing force.

Finally, there seems no better way to end - and to begin - than to insist, one more time, on colour's unsettling, wondrous ambiguity. According to Benjamin, this is precisely its strength. It allows us to both 'comprehend the reactive elements of decay (...) in modern experience' as well as to recognise 'those elements which might be recast and transformed' (Caygill, 1998: 29). Colour reveals and deceives, is both magic and poison. Perhaps, '[c]olor shines and wants only to shine' (Heidegger, 2002: 25), but then its allure and capacity to affect simultaneously turn this 
unmanageable thing into a perhaps unrivalled organizational tool. As the scenes gathered above have shown, apprehending the chromatic condition of organization throws off paradoxes like sparks: colour as managed and unmanageable; as technology and disruption of organization; as what cannot be represented and what is invariably at work in representation; as force of life and of death; as superior to mere criticism yet evading capture and co-optation. To paraphrase Deleuze (2005: 99), then, the flesh of organization calls for a montage of broken tones.

\section{Notes}

1 The notion of aesthetic force is taken from Christoph Menke's (2013) reading of Herder's nonteleological concept of force. Similar to contemporary notions of affect, force designates "pure" relation, since it exists in the relation, in connecting, and is expressed through the succession of "connectings" (exceeding any particular expression). Therefore, '[t]he aesthetic force is an endless generation and dissolution of expressions, an endless transformation of one expression into something different. Thus the operation of the aesthetic force consists in transcending, moment by moment, what it itself has produced" (p. 44), both revealing and concealing it. With regard to either instrumental or aesthetic (Taylor and Hansen, 2005) or critical (Carr and Hancock, 2003) approaches to organizational aesthetics, it should be noted that for this kind of aesthetic anthropology it is the very play of expressions of aesthetic force that enable the formation of rational wo/man (who can then pose the aesthetic as his/her other and critically unveil the machinations of aesthetic play). 2 In its original German, the Theory of Colours is structured into three parts: didactical, polemical and historical. Only the didactical part has been translated into English.

${ }^{3}$ See Kavanagh (2004) for a critique of organization studies' 'ocularcentrism' that, in this context, testifies to the brilliance and clairvoyance (to stick to visual metaphors) of Goethe's critique, and to 
what might have been lost in discarding the sensibility of the Theory of Colours. Crary (1988: 3-4) emphasizes the radicalism of the 'stunning' move away from the 'order of the camera obscura'. Goethe (1840: 16-17) closes the camera's hole and instructs the observer to "simply" focus on the dark room, thereby discarding the distinction between a separate outer and inner space, opening up experience towards fluid and unbridled chromatic transformation that a camera would never capture.

${ }^{4}$ Consider how the chemist Friedlieb Ferdinand Runge, as a young scholar once supported by old Goethe, found a brilliant blue he called Kymol in 1833 (Kane, 2014): As part of his experiments with coal tar, he coated his outdoor fence with a mix of the tar and other chemicals to hold off dogs and prevent them from urinating on the fencing. It did not work. But what a surprise, then, to find out that the melange of carnine urine and coal tar led to the emergence of a fluorescent blue.

5 The novelist stages a séance of IG Farben executives (Pynchon, 2000: 166), in which the spirit of Walter Rathenau - famed industrialist, writer and economic policymaker who promoted industry cartels and was murdered by right-wing extremists in 1924 - is summoned to give advice. At first, the spirit expounds the birth of the chemical industry from coal-tar dyes: 'A thousand different molecules waited in the preterite dung. This is the sign of reavealing. Of unfolding. This is one meaning of mauve, the first new colour on Earth (...)'. Yet there is more to come: 'But this is all the impersonation of life. The real movement is not from death to any rebirth. It is from death to deathtransfigured'.

6 In this context, Blaszczyk's metaphorical speech of commodity colourists as 'insurgents in this war for the liberation of taste', of 'command posts (...) buried deep in American industry', their officers wearing 'the insignia of the colour corps' (2012: 1), takes on a sinister tone, indeed. Even if one assumes that '[t]he colour revolution was uniquely American' (p. 16), it seems odd that a business history of colour and colour management does not mention IG Farben or acknowledge the "prehistory" of commercializing colour through colonial exploitation. 
7 IG Farben should not be directly equated with the National Socialist Party. According to Hayes' (2001) archival study (and as Pynchon knew), corporate decisions were at least to some extent based on technological and commercial logics throughout the Nazi period, too. IG Farben's 1933 contract with the state and the militarization of production in the 1930 and 1940 s mirror that of Imperial Chemical Industries in Britain and DuPont in the U.S. Also, comparably easy availability of raw materials and decent transport options as well as state pressure, and not the presence of the nearby concentration camp, seems to have led to the original decision to build a Buna plant near Auschwitz. However, choosing this site led to expansion of the camp, to the willing use of inmates as a brutal form of slave labour and 'its eventual evolution into a manufacturer of death' (p. 350). And IG Farben was a major player in seizing factories in conquered countries, adapting them to the Nazi war machine.

8 The commodification of colour is again at the heart of the reconfiguration of social relations of production: it 'led the charge into the application of the actuarial principle to human subjectivity' (Cubitt, 2014: 140). In the first half of the 2oth centuy, colour was subjected to the law of averages and the statistically derived norm of the standard observer. This way, colours could be ordered, separated from objects and mapped unto cards, chips and tableaux. In other words, the probabilistic world of risk management and biopolitical governance is connected to the taming and ordering of colour (Cubitt, 2014).

${ }^{9}$ Reaching back into antiquity, there has been a longstanding polemic between the clarity and strength of line, form and structure (read: reason, truth) and the messiness, unreliability and offensiveness of colour (read: emotion, conceit). In the mid-sixteenth century, at the height of the Renaissance, it took on the form of the both artistic and conceptual struggle between Florentine disegno and Venetian colore. The work of the Venetians and later colourists was deemed an 'insurrection of colour', a revolt in the name of 'cosmetics, pleasure and seduction', a eulogy of 'the purely material qualities of representation' turned against a mimetic, narrative and representational mode of pictorialism (Lichtenstein, 1993: 4, 5). Disegno remained the dominant paradigm of painting 
until well into the nineteenth century (Lichtenstein, 1993). Indeed, it seems very much alive, in different forms, until today, for instance in the practices and reflections of constructivism and conceptual art, so mistrustful of colour's power to deceive (Buchloh, 2008).

\section{References}

Adorno, T.W. (1984). The essay as form. New German Critique, 32, 151-171.

Albers, J. (2013). Interaction of Colour (50 ${ }^{\text {th }}$ Anniversary Edition). New Haven: Yale University Press. Batchelor, D. (Ed.) (2008). Colour (Documents of Contemporary Art). Cambridge, US: MIT Press. Batchelor, D. (2014). The Luminous and the Grey. London: Reaktion Books.

Baudrillard, J. (2005). The System of Objects, transl. J. Benedict. London: Verso.

Bell, E., Warren, S., \& Schroeder, J. (Eds.) (2014). The Routledge Companion to Visual Organization. Milton Park: Routledge.

Benjamin, W. (1979). One-Way-Street and Other Writings, transl. E. Jephcott \& K. Shorter. London: NLB.

Benjamin, W. (2002). The Arcades Project, transl. H. Eiland \& K. McLaughlin. Cambridge, US: Harvard University Press.

Benjamin, W. (2011a). A child's view of colour. In Walter Benjamin: Early Writings, 1910-1917, trans.

H. Eiland and Others. Cambridge, US: Belknap Press, pp. 211-213.

Benjamin, W. (2011b). The rainbow: a conversation about imagination. In Walter Benjamin: Early Writings, 1910-1917, trans. H. Eiland and Others. Cambridge, US: Belknap Press, pp. 214-223. Beyes, T. (2016). Art, Aesthetics and Organization. In B. Czarniawska (Ed.), A Research Agenda for Management and Organization Studies. Cheltenham: Edward Elgar, forthcoming.

Beyes, T. \& Steyaert, C. (2012). Spacing organization: non-representational theory and performing organizational space. Organization, 19, 45-61.

Beyes, T., \& Steyaert, C. (2013). Strangely familiar: The uncanny and unsiting organizational analysis. Organization Studies, 34, 1445-1465. 
Biggam, C.P. (2015). The Semantics of Colour: A Historical Approach. Cambridge, UK: Cambridge University Press.

Blaszczyk, R.L. (2012). The Colour Revolution. Cambridge, US: MIT Press.

Borch, C. (2010). Organizational atmospheres: Foam, affect and architecture. Organization, 17, 22341.

Brusatin, M. (1991). A History of Colors, transl. R.H. Hopcke \& P. Schwartz. Boston: Shambhala.

Buchloh, B.D. (2008). The diagram and the colour chip: Gerhard Richter's 4900 Colours. In Serpentine Gallery (Ed.), Gerhard Richter-490o Colours (pp. 61-71). Ostfildern: Hatje Cantz. Buchloh, B.D. (2012). The chance ornament: Aphorisms on Gerhard Richter's abstractions. Art Forum, February 2012, 168-181.

Carr, A., \& Hancock, P. (Eds.) (2003). Art and Aesthetics at Work. Basingstoke: Palgrave Macmillan. Caygill, H. (1998). Walter Benjamin: The Colour of Experience. London: Routledge.

Cohen, J., \& Matthen, M. (Eds.) (2010). Color Ontology and Color Science. Cambridge, US: MIT Press.

Connellan, K. (2013). The Psychic Life of White: Power and Space. Organization Studies, 34, 15291549.

Cooper, R. (2005). Peripheral Vision: Relationality. Organization Studies, 26(11): 1689-1710.

Crary, J. (1988). Techniques of the Observer. October, 45, 3-35.

Crary, J. (2006). Illuminations of the Unforeseen. In I. Soyugenc \&. R. Torchia (Ed.), Olafur Eliasson: Your Colour Memory. Glenside, US: Arcadia University Art Gallery.

Cubitt, S. (2014). The Practice of Light: A Genealogy of Visual Technologies from Prints to Pixels. Cambridge, US: MIT Press.

Dale, K., \& Latham, Y. (2015). Ethics and entangled embodiment: Bodies-materialitiesorganization. Organization, 22, 166-182.

Delamare, F., \& Guineau, B. (2000). Colour: Making and Using Dyes and Pigments, transl. S. Hawkes. London: Thames \& Hudson. 
Deleuze, G. (2005). Francis Bacon: The Logic of Sensation, transl. D.W. Smith. London: Continuum. Duchamp, M. (1966). Apropos of 'Readymades'. Art and Artists, 1, 47.

Eaton, N. (2013). Colour, Art and Empire: Visual Culture and the Nomadism of Representation. London: I.B. Tauris.

Finlay, R. (2007). Weaving the rainbow: Visions of colour in world history. Journal of World History, $18,383-431$.

Gage, J. (1995). Colour and Culture: Practice and Meaning from Antiquity to Abstraction. London: Thames \& Hudson.

Gage, J. (1999). Colour and Meaning: Art, Science and Symbolism. London: Thames \& Hudson. Gagliardi, P. (2006). Exploring the aesthetic side of organizational life. In S. Clegg et al. (Eds.), The Sage Handbook of Organization Studies (pp. 701-724). London: Sage.

von Goethe, J.W. (1840). Theory of Colours, transl. C.L. Eastlake. London: John Murray. Hansen, M.B.N. (2013). Ubiquitous sensation: Toward an atmospheric, collective, and microtemporal model of media. In U. Ekman (Ed.), Throughout: Art and Culture Emerging with Ubiquitous Computing (pp. 63-88). Cambridge, US: MIT Press.

Hayes, P. (2001). Industry and Ideology: IG Farben in the Nazi Era, $2^{\text {nd }}$ ed. Cambridge: Cambridge University Press.

Hayles, N.K., \& Eiser, M.B. (1985). Colouring Gravity's Rainbow. Pynchon Notes, 16, 3-24.

Heidegger, M. (2002). The origin of the work of art. In M. Heidegger, Off the Beaten Track, transl. J. Young \& K. Haynes (pp. 1-56). Cambridge, UK: Cambridge University Press.

Helin, J., Hernes, T., Hjorth, D. \& Holt, R. (2014). Process is how process does. In J. Helin et al. (Eds.), The Oxford Handbook of Process Philosophy and Organization Studies (pp. 1-16). ).Oxford: Oxford University Press.

Holt, R., \& Cornelissen, J. (2014). Sensemaking revisited. Management Learning, 45, 525-539. Jameson, F. (2013). The Antinomies of Realism. London: Verso. 
Kane, C.L. (2014). Chromatic Algorithms: Synthetic Colour, Computer Art, and Aesthetics after Code. Chicago: University of Chicago Press.

Kavanagh, D. (2004). Ocularcentrism and its others: A framework for metatheoretical analysis. Organization Studies, 25, 445-464.

Kittler, F. (1999). Gramophone, Film, Typewriter, transl. G. Winthrop-Young \& M. Wutz. Stanford: Stanford University Press.

Kittler, F. (2006). Thinking Colours and/or Machines. Theory, Culture \& Society, 23, 39-50.

Knox, H., O'Doherty, D.P., Vurdubakis, T., Westrup, C. (2015). Something happened: Spectres of organization/disorganization at the airport. Human Relations, 68, 1001-1020.

Küpers, W. (2014). Between the visible and the invisible in organizations. In E. Bell, S. Warren \& J. Schroeder (Eds.), The Routledge Companion to Visual Organization (pp. 19-32). Milton Park: Routledge.

Lavin, S. (2004). What Colour Is It Now?. Perspecta, 35, 98-111.

Lichtenstein, J. (1993). The Eloquence of Colour: Rhetoric and Painting in the French Classical Age, transl. E. McVarish. Berkeley: University of California Press.

Linstead, S. (2000). Ashes and madness: The play of negativity and the poetics of organization. In S. Linstead and \& H. Höpfl (Eds), The Aesthetics of Organization (pp. 61-92). London: Sage.

Manning, E. (2008). Coloring the Virtual. Configurations,16, 325-346.

Manning, E., \& Massumi, B. (2014). Thought in the Act: Passages in the Ecology of Experience. Minneapolis: University of Minnesota Press.

Martin, R. (2003). The Organizational Complex: Architecture, Media, and Corporate Space. Cambridge, US: MIT Press.

Massumi, B. (2002). Too-blue: Color-patch for an expanded empiricism. In B. Massumi, Parables for the Virtual: Movement, Affect, Sensation (pp. 208-256). Durham, US: Duke University Press. Menke, C. (2013). Force: A Fundamental Concept of Aesthetic Anthropology. New York: Fordham University Press. 
N.N. (1957). Die gefährliche Farbe. Der Spiegel, 44, 58-61.

O'Doherty, D.P. (2008). The blur sensation: Shadows of the future. Organization, 15, 535-561.

O'Doherty, D.P., De Cock, C., Rehn, A., \& Ashcraft, K.L. (2013). New sights/sites: Exploring the white spaces of organization. Organization Studies, 34, 1427-1444.

Palmer, S.E. (1999). Vision Science: Photons to Phenomonology. Cambridge, US: MIT Press.

Pastoureau, M. (2001). Blue: The History of a Colour, transl. M.I. Cruse. Princeton: Princeton

University Press.

Pastoureau, M. (2009). Black: The History of a Colour, transl. J. Gladding. Princeton: Princeton University Press.

Pelzer, B. (2008). The Asymptote of Chance. In Serpentine Gallery (Ed.), Gerhard Richter- 4900 Colours (pp. 117-131). Ostfildern: Hatje Cantz.

Pickering, A. (2005). Decentering Sociology: Synthetic Dyes and Social Theory. Perspectives on Science, 13, 352-405.

Pynchon, T. (2000). Gravity's Rainbow. London: Vintage.

Rancière, J. (2004). The Politics of Aesthetics: The Distribution of the Sensible, transl. G. Rockhill. London: continuum.

Rancière, J. (2013). Aisthesis: Scenes from the Aesthetic Regime of Art, transl. Z. Paul. London: Verso. Reckwitz, A. (2012). Die Erfindung der Kreativität: Zum Prozess gesellschaftlicher Ästhetisierung. Frankfurt am Main: Suhrkamp.

Riley, C.A. II (1995). Color Codes: Modern Theories of Color in Philosophy, Painting and Architecture, Literature, Music, and Psychology. Hanover and London: University Press of New England.

Sepper, D.L. (1988). Goethe Contra Newton: Polemics and the Project for a New Science of Colour.

Cambridge, UK: Cambridge University Press.

Strati, A. (2010). Aesthetic understanding of work and organizational life: approaches and research developments. Sociology Compass, 4, 880-893.

Taussig, M. (2008). Redeeming Indigo. Theory, Culture \& Society, 25, 1-15. 
Taussig, M. (2009). What Colour is the Sacred? Chicago: University of Chicago Press.

Taussig, M. (2012). Beauty and the Beast. Chicago: University of Chicago Press.

Taylor, S. S., \& Hansen, \& H. (2005). Finding form: Looking at the field of Organizational Aesthetics. Journal of Management Studies, 42, 1211-1231.

Thrift, N. (2008). The material practices of glamour. Journal of Cultural Economy, 1, 9-23.

Thrift, N. (2012). The insubstantial pageant: producing an untoward land. Cultural Geographies, 19, $141-168$.

Warren, S. (2008). Empirical Challenges in Organizational Aesthetics Research: Towards a Sensual Methodology. Organization Studies, 29, 559-580.

Wittgenstein, L. (1978). Remarks on Colour, transl. L.L. McAlister \& M. Schättle. Berkeley: University of California Press. 